\title{
顎関節内障クローズドロック症例に対する外科療法の検討
}

一䫓関節開放手術術後成績について一

\author{
川上哲司・匠原悦雄・都築正史・高山賢一 \\ 大河内則昌・杉村 正 仁
}

\section{Postoperative follow-up study of closed lock cases after open surgery of the temporomandibular joint}

\author{
Tetsuji Kawakami $\cdot$ Etsuo Shohara $\cdot$ Masashi Tsuzuki $\cdot$ Ken-ichi TaKayama \\ Norimasa OHKouchi $\cdot$ Masahito Sugimura
}

\begin{abstract}
Open surgery for internal derangement of the temporomandibular joint was performed in 9 patients, 10 joints. Postoperative follow-up studies of 17 months or more are described.

Satisfactory results were obtained in 8 cases, 9 joints according to the criteria of the American Society of Oral and Maxillofacial Surgery in 8 cases, 8 joints according to the criteria of Takahashi and Shibata. No surgical complication or postoperative severe discomfort was encountered. The surgical success rate was $88.9 \%$.
\end{abstract}

Key words: internal derangement of the temporomandibular joint (顎関節内障), open surgery (外科療法), follow-up study（追跡調査）

\section{緒言}

顎関節・咀嚼筋などの咀嚼器官の不調を主訴とする 顎関節症患者は当科においても, 年々著明な増加傾向 をみている. 顎関節症の中でも疼痛を伴う開口障害を 主症状とし関節円板の転位や変形, 関節内癒着などを 合併し複雑な病態を呈する顎関節内障クローズドロック 症例に対して, 外科療法を行い 17 か月以上経過観察を行っ た 9 例 10 関節について評価を行ったので報告する.

\section{対}

\section{象}

クローズドロック症例に対する外科療法の目的とし ては, 外科的に下顎頭関節円板複合体の可動性を増加 させ, 顎関節機能の回復を図ることとした．

対象症例としては, 顎関節内障クローズドロックと 診断し, スプリント療法, マニピュレーション療法 （パンピングマニュピュレーション療法を含む）など の保存療法を約 6 か月以上行ったが奏功しない経過の

奈良県立医科大学口腔外科学教室

(主任 : 杉村正仁教授)

Department of Oral and Maxillofacial Surgery, Nara Medical University (Chief: Pro. Masahito

Sugimura)

受付日：平成 6 年 4 月 20 日
長いクローズドロック症例であり, 1991 年 8 月から 1992 年 5 月までの期間に外科療法を施行した 9 例 10 関節である。主に開口障害が著明なもの 3 例, 顎運動 時痛が著明なもの 6 例であった。 また, 術前の顎関節 造影検查または MRIによる画像診断にて復位のない 関節円板前方転位を確認しており，術後 17 か月以上 経過観察を行った。手術時年齢は, 平均 $47.4 \pm 15.7$ 歳, すべて女性で, 初診時主訴は, 開口障害 3 例・顎関節 部の開口時痛 6 例, 患側は両側性 1 例 - 右側 5 例 - 左 側 3 例であった.クローズドロック期間は平均 $11.9 \pm$ 5.9 か月で, 全例関節雑音の既往があり, 雑音既往期間 は平均 $26.7 \pm 18.4$ か月であった。 また, 全例顎運動時 痛を認め, 開口度は平均 $26.7 \pm 5.6 \mathrm{~mm}$, 前方運動量平 均 $3.3 \pm 1.8 \mathrm{~mm}$, 患側への側方運動量 $3.1 \pm 1.2 \mathrm{~mm}$, 健 側への側方運動量 $4.1 \pm 0.9 \mathrm{~mm}$ であった（表 1 ）.

\section{方法}

術前に顎関節二重造影断層検査または MRI 検査を 行い, 全身麻酔下にて開放手術に先立って顎関節鏡検 査を施行した，各症例に対する手術内容は，全例経鼻 挿管下の全身麻酔により施行し, Dolwick ${ }^{1)}$ の方法に 準じた円板整位術を施行したもの 9 例 9 関節，円板穿 孔部縫縮術を行ったもの 5 例 5 関節, 円板切除術を行っ 
表 1 顎関節内障クローズドロック手術症例

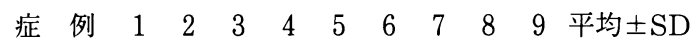

年齢(歳) $32 \quad 53 \quad 47 \quad 17 \quad 64 \quad 37 \quad 38 \quad 62 \quad 47$

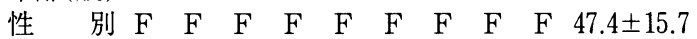

患 側右 右 左 右 右 左 左 右左

主訴開口疼痛疼痛疼痛疼痛開口疼痛疼痛開口

障害障害障害

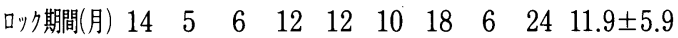

顎関節痛 +++++++++

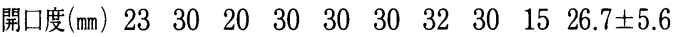

運動量 ( $\mathrm{mm}$ )

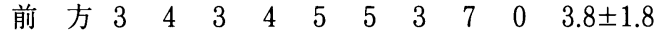

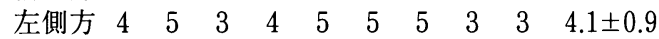

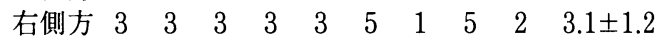

関節雑音 - - - - - - -

表 2 顎関節内障クローズドロック手術内容

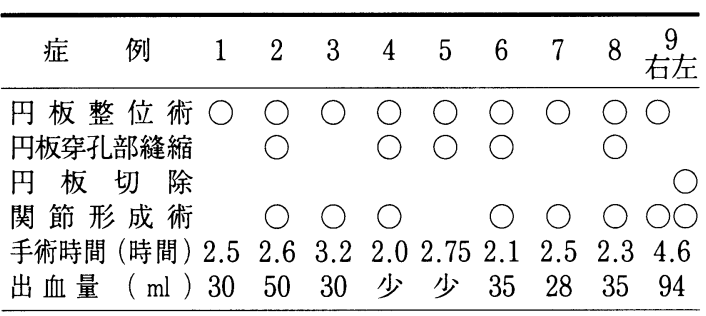

表 3 造影, 鏡視および手術所見

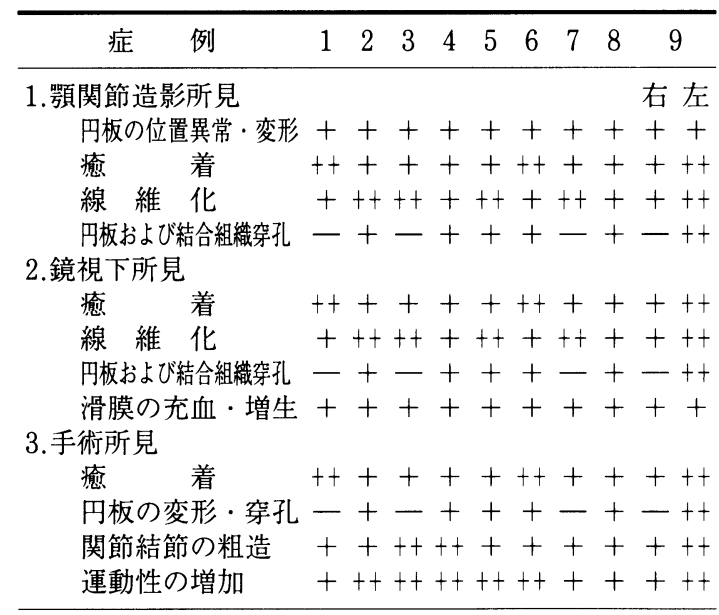

たもの 1 関節, 関節結節の骨増生または下顎頭の骨棘 に対して関節形成術をあわせて施行したもの 7 例 8 関 節であった. 穿孔をともなう症例に対しては穿孔部が 円板と後部結合組織の移行部にあり径が小さくかつ円 板の復位が可能であれば円板整位術に合わせて穿孔部 を含めた同部の楔状切除を行い縫合した．また，穿孔 が広範囲におよび円板の変形と変性が著明のときは円 板切除術を施行した (表 2 ). 術後よりスタビライゼイ ション型スプリントを装着させ, 約 3 日間は前方・側
表 4 顎関節内障クローズドロック手術術後成績

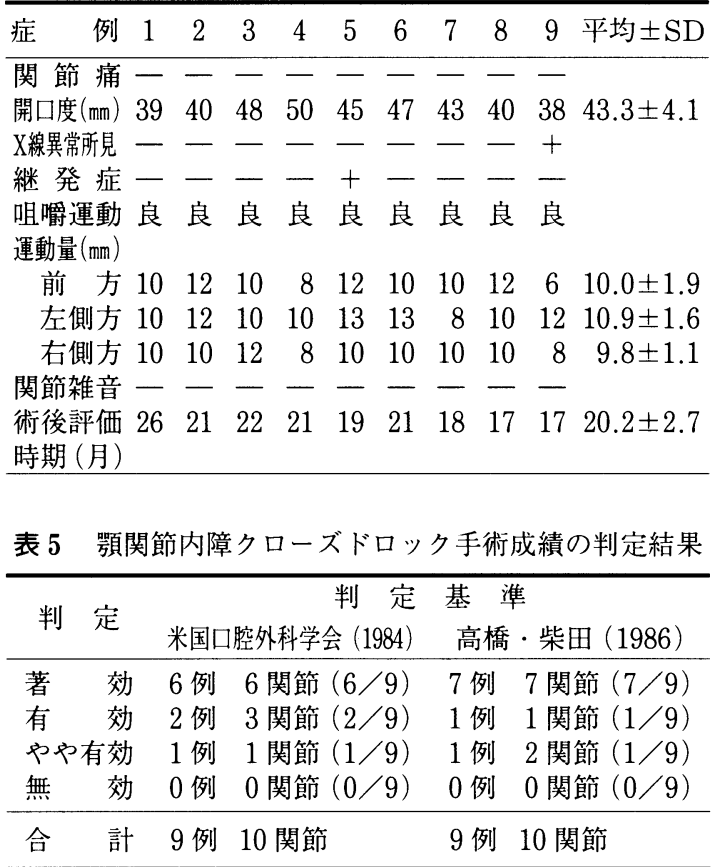

方運動を中心に行なわせ，以後それに加えて開口練習 を積極的に行わせ, 症状軽減するとともに最終補緅を 施行し治療を終了した。

\section{結果}

\section{1. 造影, 鏡視および手術所見について}

術前の䪽関節造影所見では, すべての症例において 円板の位置異常 - 変形, 癒着および線維化が認められ, 6 例において円板穿孔が認められた。関節鏡視下所見 では, 全症例において癒着・線維化を認めたため, 上 関節腔後方滑膜間腔は容易に鏡視可能であったが，前 方滑膜間腔は関節鏡を関節結節の前方に進めることは 困難であった. 手術所見では, 造影所見・鏡視下所見 に対応して, 癒着による運動性の低下と関節円板の穿 孔を確認することができた. そして，特に疼痛を訴え た症例において関節結節下面から後面にかけての骨粗 造が著明に認められた（表 3 ).

手術時間は，1 関節につき約 $2.4 \pm 0.3$ 時間, 出血量 は, 円板切除術を施行した症例において $94 \mathrm{ml}$ とやや 多かった (表 2 ).

\section{2 . 術後成績について}

各症例の術後成績の判定は, 術後 17 から 26 か月 (平均 $20.2 \pm 2.7$ か月) までの間に行った. 開口度は術 前平均 $26.7 \mathrm{~mm}$ 加術後平均 $43.3 \pm 4.1 \mathrm{~mm}$ に改善さ れ, 顎運動時痛は消失し患側においても不自由なく咀 嚼可能となった.しかし，1例において顔面神経麻瘏 が約 3 か月間認められた。他の 1 例については円板切 
除術を施行した関節において下顎頭の平坦化が認めら れるが現在のところ進行はなく, 臨床症状との関連は 認めない. 前方運動量は平均 $10 \pm 1.9 \mathrm{~mm}$, 患側への側 方運動量平均 $9.9 \pm 1.6 \mathrm{~mm}$, 健側への側方運動量平均 $10.9 \pm 1.2 \mathrm{~mm}$ と改善された（表 4 ).

さらに日覚症状の術前術後の变化について, アンケー トによる定量的評価を行った，疼痛の visual analogue Scale, 顎疼痛, 占数, 顎機能障害别数のいずれも術 後著明な改善が認められた。

\section{3 . 術後成績の判定結果について}

2 つの判定基準による術後成績の判定を行った。米 国口腔外科学会による判定基準 2 )では 8 例 9 関節に, 高橋・柴田による顎関節内障手術の効果判定基準 3 )にお いては 8 例 8 関節に満足できる評価が得られ, 有効以上 8 8.9\%であった．また，外科療法により無効であったもの， 症状の増悪や悪化を米したものはなかった（表 5 ).

\section{考察}

顎関節内障クローズドロック症例に対する外科療法 の適忍症として, 高橋・柴田 ${ }^{3)}$ は(1)経過の長い復位を 伴わない関節円板前内方転位例, (2)穿孔を伴う関節円 板前内方転位例, (3)頻繁に発現する間欠的ロック症例, (4)保存的療法が奏功しない病歴の長い関節円板前内方 転位例であるとのべている. 今回のわれわれの遭遇し た症例においても, スプリント療法, マニピュレーショ ン療法 (パンピングマニピュレーション療法を含む) などの保存療法が奏功せず, 造影所見や鏡視所見で, 癒着および線維化が高度で, 円板の位置異常, 変形・ 円板穿孔拉よび骨変形が認められるものを本手術の適 忍とし, 主目的は顎運動時痛なく $40 \mathrm{~mm}$ 程度の開口が でき，患側においても咀嚼可能となるように関節窩下 面における関節円板の滑走性の回復を与えることとし た。また，特に疼痛を訴えた症例において術中所見で は，関節結節下面から後面にかけての骨粗造が著明に 認められ，滑膜炎に加えてこれが疼痛の原因になって いると思われた。従ってこの反心性の骨増生や下顎頭 の骨棘に対して関節結節および下顎頭修正術を行った. これにより疼痛は著明に軽減した。

近年,クローズドロック为例に対して関節鏡視下剥 離授動術が施行されており良好な結果が得られている ようである ${ }^{4)}$.しかしこれには関節内の剥離操作，特 に関節包外側付着部の十分な剥離操作が必須であり, これが不十分であると良好な症状の改善と機能回復が 得られない.また, 村上 ${ }^{5)}$ は, 病期の進行して関節円 板の転位と変形が高度な症例や, 穿孔をともなった症 例には適心となり得ないであろうと述べており，やは り, 剥離操作が十分に行えない場合や，罹病期間が長 く 1 年以上を経過するもの, 罹病期間が短くとも高度 の円板穿孔泟例では顎関節開放手術が必須と考えられる。 術後成績の判定では, 村上ら ${ }^{6)}$ は術後平均 3 年 4 か
月で奏功率が $93 \%$ あったとし, 佐藤ら ${ }^{7)}$ は米国口腔 外科学会の判定基準 2 ) では $86.3 \%$, 高橋. 柴田の判定 基準 ${ }^{3)}$ では $93.3 \%$ と報告しているが，今回のわれわれ の結果も $88.9 \%$ と同様の奏功率が得られた。また，無 効と判定されたもの・症状の増悪や悪化を来したもの はなかったが，1例に扔いてやや有効であった。これ は症例 9 であり術後X 線学的に下顎頭において中等 度の骨吸収が認められたためである。しかし，臨床症 状との関連性はなく経過観察中である.さらにこの症 例は筋無力症状を呈し術後顎運動訓練が十分に行なわ れなかったことも一理あると思われる。また，術中左 側において関節円板の著明な変形と瘉着を認め, 円板 切除術を施行したためと思われる。

\section{結語}

1. 顎関節内障クローズドロック症例 9 例 10 関節 に対する外科療法の術後成績について検討した。

2. 術後 17 か月以上経過観察した術後成績は, 有効 以上 $90 \%$ であった。

3. すべての症例で, 開口度は $38 \mathrm{~mm}$ 以上, 前方 · 側方運動量は $6 \mathrm{~mm}$ 以上に改善された.

4. 顎関節の疼痛は, すべての症例において消失した.

5. 術後, 患側においても不自由なく咀嚼可能となった

6.1例において一時的な顔面神経麻痺が認められた.

本論文の要旨は 1993 年 10 月 21 日, 第 38 回日本口腔 外科学会総会 (新潟)に扔いて発表した。

\section{引用文 献}

1) Dolwick, M.F. and Sanders, B.: Temporomandibular joint internal derangement and arthrosis. A surgical atlas. Mosby St Louis, 1985. 1 -321.

2) Ad Hoc Study Group on TMJ Meniscus Surgery: 1984 Criteria for TMJ Meniscus Surgery. American Association of Oral and Maxillofacial Surgeons, Chicago, 1984, $1-40$.

3）高橋庄二郎, 柴田孝典：顎関節の基礎と臨床。 日本歯科評論社. 東京. 1986. 207-242.

4）瀬上夏樹, 森家祥行, 他：顎関節内障に対する 関節鏡視下剥離授動術の評価一病期分類に基づ く検討一. 日顎誌. 4 ：49-57 1992 .

5）村上賢一郎, 松木優典, 他：顎関節内障に対す 万外科療法の適応と術後評価. 日口外誌 34 : 1132-1139 1988.

6）村上賢一郎, 宮木克明, 他：顎関節内障に対す る関節円板整復術の術後評価と下顎頭のエック 又線学的変化. 日只外誌 $36: 1887-18951990$.

7）佐藤修一, 川村 仁, 他：顎関節内障に対する 円板整復術の術後評価について. 日顎誌 4 : 91 981992. 